This item is the archived peer-reviewed author-version of:

Beyond the bird in the cage? Translocal embodiment and trajectories of Nicaraguan female migrants in Seville, Spain

\title{
Reference:
}

Winters Nanneke.- Beyond the bird in the cage? Translocal embodiment and trajectories of Nicaraguan female migrants in Seville, Spain Geoforum - ISSN 0016-7185 - (2018), p. 1-9

Full text (Publisher's DOI): https://doi.org/10.1016/J.GEOFORUM.2018.05.019

To cite this reference: https://hdl.handle.net/10067/1516610151162165141 


\section{Beyond the bird in the cage? Translocal embodiment and trajectories of Nicaraguan female migrants in Seville, Spain}

Nanneke Winters - Institute of Development Policy (IOB), University of Antwerp

\section{Abstract}

In migration scholarship, the migrant body has recently begun to gain recognition as a productive analytical scale for exploring politics of mobility: the highly differentiated ways in which migration is accessed and lived. However, a tendency to treat bodies as sites of gendered and racialized suffering can obscure migrant agency and differentiation as well as the ways in which migrant bodies can also be seen as sites of resistance and achievement. This paper aims to contribute to our understanding of the ways in which mobility politics shape divergent migrant trajectories by putting forward a translocal embodiment perspective. The paper argues that migrant bodies constitute key sites of struggle over mobility, and that looking at migrant embodied practice in translocal context can further unravel the differentiations that shape migrant trajectories across space and time. The paper's argument builds on theoretical notions of intersectionality, embodied cultural capital and translocality to enrich the discussion of mobility politics. Empirically, it draws on multi-sited ethnographic research with Nicaraguan families, focusing on female Nicaraguan migrants working in informal domestic employment in Spain, to explore how bodies and embodied practices matter throughout these migrants' trajectories. In particular, the paper intends to do justice to migrant agency by exploring how bodies that are often victimized can also be considered as stratified resources of translocal negotiation. The translocal embodiment perspective put forward in the paper shows that migrant bodies constitute a multi-faceted, non-erasable component of the unsettled yet situated mobility politics that shape divergent trajectories. 
Keywords: politics of mobility, embodiment, translocality, intersectionality, migrant trajectories

\section{Introduction}

Migrant trajectories only come into being through the highly unequal border-crossings of actual human bodies. In migration scholarship, the migrant body has recently begun to gain recognition as a productive analytical scale (McDowell, 1999; see also Dunn, 2010; Hyndman, 2004; Vaittinen, 2014), exemplified in emerging embodiment perspectives that can be linked to classic feminist and gender arguments as well as to recently reinvigorated discussions on the politics of mobility. The latter maintains that the way in which migration is accessed and lived is highly differentiated based on people's context-specific socioeconomic, political and cultural positionings (Cresswell, 2010; Massey, 1993; see also Merriman, 2015). These include positionings inscribed at the body (Merriman, 2017), of which gender and race (or ethnicity) are classic examples. Research using an embodiment perspective has fruitfully addressed the role of migrant bodies in stratified global labour and migration regimes, including both the structural (geo)political categorization and management of 'docile bodies' (Hyndman, 2002) and the subjective migration experience based on a diversity of bodily characteristics, sensations and practices (Silvey, 2005, see also Blunt, 2007). Challenging disembodied (often implicitly masculine) accounts, an embodiment perspective on migration thus plays an important role in revealing the everyday operations and contestations of mobility politics (Mountz, 2004).

Although an embodiment perspective has been used for a range of migration settings, actors and experiences, ${ }^{1}$ destination country studies of specific migrant groups tend to portray migrant bodies rather uniformly as sites of gendered and racialized discrimination, marginalization and exploitation.

\footnotetext{
${ }^{1}$ Including a government workplace (Mountz, 2004); rural-to-urban subjective experiences of global labour regimes (Werner, 2010); European border-making (Schmoll, 2014); international border performance (Coplan, 2012); global care chains (Vaittinen, 2014); and the 'body work' of migrants employed in the global care sector (Dyer et al., 2008; McDowell, 2015).
} 
However, a narrow focus on migrant bodies as sites of suffering tends to obscure migrant agency and differentiation as well as the ways in which bodies can also be seen as sites of resistance and achievement, however constrained (Dunn, 2010). This becomes particularly clear when analyzing the role of migrant bodies beyond circumscribed destination settings, by including the people, places and translocal processes that constitute migrant trajectories. The particular bodies of (potential) migrants influence, amongst others, decision-making about who will migrate, why, when, where to and in what way; personal embodied experience en route, at the border, in and out of the workplace; and (future) livelihood opportunities of both migrants and their relatives 'at home'. Taking into account this broader relevance of migrant bodies throughout migrant trajectories provides an opportunity to further 'flesh out' the differentiations of migration by adding another layer of complexity and relationality to mobility politics.

Drawing on multi-sited ethnographic research with Nicaraguan families, this paper aims to contribute to our understanding of the ways in which mobility politics shape divergent migrant trajectories by putting forward a translocal embodiment perspective. The paper argues that migrant bodies constitute key sites of struggle over mobility, and that looking at migrant embodied practice in translocal context can further unravel the differentiations that shape migrant trajectories across space and time. Taking mobilities research on migration as its starting point, the argument of the paper further builds on theoretical notions of intersectionality, embodied cultural capital and translocality to enrich the discussion of mobility politics. Empirically, the paper primarily focuses on female Nicaraguan migrants working in informal domestic employment in Spain and explores how their bodies and embodied practices matter throughout their trajectories. In particular, the paper intends to do justice to migrant agency by exploring how bodies that are often victimized can also be considered as stratified resources of translocal negotiation. Migrant bodies are more than sites of suffering: a translocal embodiment perspective shows that they constitute a multi-faceted, non- 
erasable component of the unsettled yet situated mobility politics that shape divergent migrant trajectories.

Applying an embodiment perspective in this way requires some clarification on terminology and connotation. Although 'body' and 'embodiment' are highly entangled in practice and also used interchangeably in writing (McDowell, 1999: 39), the latter conveys a sense of 'performance' that is most important for my argument. I will thus focus less on bodily sensations or feelings (although these inevitably emerge as well) and more on embodied practices: the ways in which migrants make use of bodies and certain socially constructed bodily aspects ${ }^{2}$ to shape their trajectories. Such an embodiment perspective also reflects the structural, context-specific categorizations to which migrants' embodied practices respond (and which they co-produce), and migrants' ensuing identifications and positionings. Before I go into embodied practices, I will first outline a theoretical introduction to the paper and provide some methodological considerations. I then sketch the Nicaraguan and Spanish research setting and subsequently describe and analyse a selection of three embodied practices that were part of the research participants' trajectories. In conclusion, I will emphasize the relevance of focusing on migrant bodies for a well-rounded discussion of mobility politics and migrant agency, and posit some ideas for further research foregrounding translocal embodiment.

\section{Theoretical background}

\subsection{Political and relational mobilities}

Although a relatively static view of looking at migration's neatly defined starting points and ends has long dominated in migration scholarship, the so-called 'mobilities turn' in social sciences has aided

\footnotetext{
${ }^{2}$ For brevity, in the remainder of the paper I will merely use the term 'bodily aspects', without losing sight of the idea that these aspects are not natural givens, but social constructions.
} 
scholars to problematize migration itself (Cresswell, 2010; Merriman, 2015; Sheller and Urry, 2006).

Rather than taking migration as a given, mobilities research on migration interrogates the

interconnected, differentiated and contextualized nature of migration and non-migration experiences

(Schapendonk and Steel, 2014). ${ }^{3}$ Specifically, such mobilities research emphasizes how migration

relates to 'the production and distribution of power' between differently positioned social groups and individuals (Cresswell, 2010: 21), a political process that becomes materialized in specific localities (Blunt, 2007) and regimes (Glick Schiller and Salazar, 2013). Migration is not straightforward but messy, and migrant trajectories involve differently positioned people to whom mobility means different things (Cresswell, 2010: 19), for whom mobility is stratified and can be considered a stratifying factor (ibid: 22; Carling, 2002).

Similar thoughts on what has come to be known as the politics of mobility had already been articulated by Massey (1993: 61-62), in her discussion of the 'power-geometry' of 'contemporary global flows' like migration. By recognizing the power-geometries of who moves, who is in charge of movement, and who gets weakened (or strengthened) by other people's movement, Massey emphasized the fundamentally political and relational character of both migration and its social implications. In contexts heavily influenced by a 'culture of migration', where migration and wellbeing are considered to be linked (Connell, 2008), even people who are unable or unwilling to migrate are still involved in negotiations over mobility, and actual migration unevenly shapes lives and livelihoods far beyond those of migrants themselves. ${ }^{4}$ In the Nicaraguan research setting of this paper, for example, the culturally defined carework roles that distinguish different family members not only shape individual access to particular kinds of migration, but also the unequal sharing of migration's costs and benefits across borders (Winters, 2014). Context-specific social positionings that

\footnotetext{
${ }^{3}$ Some of these interconnected, context-specific differentiations have also been identified and elaborated by transnational migration studies, for example, on transnational family practices (Hondagneu-Sotelo, 1994; Mahler and Pessar, 2001) and remittances (Carling, 2014). See Hui (2016) for a discussion of the sequencing of transnational migration studies and mobility studies.

${ }^{4}$ This, too, has been recognized by transnational migration studies, for example in the notion of transnational social fields (Glick Schiller and Levitt, 2006), but largely from the standpoint of migration as a given.
} 
inform mobility politics are thus constitutive of highly differentiated migration experiences and implications (Herrera, 2013).

\subsection{Gender and intersectionality}

One of the main social positionings that underpins mobility politics and serves as a differentiating principle of migration, concerns gender relations (Hondagneu-Sotelo, 1994; Mahler and Pessar, 2001). The recognition of women as active participants in migration, and of the differences between female and male migrants, has advanced migration studies through uncovering female migrant experiences and subsequently exploring the fundamentally gendered nature of migration (Herrera, 2013). In particular research on transnational families and on the local-to-global commodification of carework has served to redress a largely individualized, masculine migration discourse by analysing the gendered norms, practices and experiences that shape migration processes (Anthias, 2012; Dyer et al., 2008; Mountz and Hyndman, 2006).

More recently, however, and in tune with ongoing developments in feminist and gender studies, migration scholars recognize the need to explicitly integrate gendered analyses of migration with an intersectional approach (Herrera, 2013). Established by critical race studies in the late 1980s (Nash, 2008) as an academic as well as a political project for social justice (Bilge, 2013), an intersectional approach foregrounds simultaneously interlocking axes of difference, including gender, ethnicity, class, age and ability (Anthias, 2012; Bastia et al., 2011; Sinatti, 2014). Although subject to ongoing discussion and elaboration (see for example Bilge, 2013; Nash, 2008), an intersectional approach provides a way of thinking that helps de-essentialise complex categories of people, women in particular, by integrating various interlinked, contextual social positionings that account for intragroup heterogeneity (Anthias, 2016; Bastia, 2014; Bastia et al., 2011). In migration studies, for example, an intersectional approach can help move beyond the essentialising of migrant communities and ethnic groups as natural, homogeneous categories (Amelina and Faist, 2012; 
Bürkner, 2012; Glick Schiller and Salazar, 2013). It thus enables a better understanding of the differentiated migration experience of people from a single area, based on time- and place-specific intersections of being female or male, old or young, affluent or underprivileged, and so forth.

An intersectional approach typically also integrates multiple scales of differentiation, moving beyond structure-agency dualisms by putting forward complementarities rather than mutually exclusive explanations (Bürkner, 2012). Social differentiations are produced, negotiated and re-produced across multiple scales, including those of ideology, governance, neoliberal institutions, migration patterns, and everyday practices (McDowell, 2008). These hallmarks of the intersectional approach, in which social positionings are a result of interlocking axes of difference that are constructed across multiple scales, provide key steps towards a recognition of the role of migrants' bodies in the mobility politics that shape divergent migrant trajectories.

\subsection{Embodiment across social and spatial scales}

In part, the 'gendering' of migration studies took place thanks to a greater recognition and exploration of the role of relatively intimate, small-scale geographies such as the workplace, the household and the individual in global dynamics (McDowell, 1999; 2015; Mountz, 2004; Nagar et al., 2002). In tune with this, since the mid-1990s feminist migration researchers have begun to examine the body as a productive scale of analysis at the intersection of structure, discourse and action (Hyndman, 2004; McDowell, 2008; Silvey, 2005; see also Schmoll, 2014). By foregrounding migrants' bodies and examining migration as embodied, a deeper understanding of mobility politics (Dunn, 2010: 5) and migration differentiations (Silvey, 2005: 144) can be generated.

As mentioned above, an embodiment perspective on migration has been explored in a number of diverse migration settings. The principal case I will take up in this paper, of female Nicaraguan migrants working in informal domestic employment in Spain, reflects one of the most palpable of 
these settings: the often precarious 'body work' performed in the increasingly important and recognized global carework sector (Anderson and Shutes, 2014; Hochschild, 2000). This sector includes body work as diverse as cleaning, comforting and hosting, in private and public settings, and requires a certain degree of co-presence and specific embodied practices that enable workers to enact the intimate gendered/racialized performances that employers expect (Dyer et al., 2008; McDowell, 2015)..$^{5}$ The key role of embodiment in this type of work generates (migrant) worker differentiation based on their sex, skin colour, size, ability, accent, age, and migration status (McDowell, 2015). Through embodiment, the sector constructs migrants' appropriateness for specific care jobs (McDowell, 2008), defines which bodies belong where (Vaiou, 2012), and (re)produces precarious migrant niches in labour markets and, relatedly, non-work settings (Buckley et al., 2017). Migration scholarship that considers migrant bodies, including studies of the global carework sector, has often focused on these bodies' marginalization in specific destination settings. ${ }^{6}$ This paper uses two strategies to redress this victimizing tendency: first, a focus on mobile or migration-specific embodied cultural capital (Erel, 2010; Kelly and Lusis, 2006), and second, a simultaneous inclusion of multiple social and geographical locations (ibid; Mahler et al., 2015). Regarding the first, migrant bodies are more than stigmatized and exploited: they can also be appropriated as resources to shape trajectories by deploying migrants' embodied familiarity with and employment of social and professional norms prevalent in a foreign environment. Examples include mastering a local language (or accent) and taking advantage of ethnic stereotyping. The migration literature tends to ignore the importance of this kind of mobile or migration-specific embodied capital, which forms part of the more tacit, 'elusive' resources that are 'difficult to separate out from everyday practices, social

\footnotetext{
${ }^{5}$ Although body work is highly diverse, its supposedly feminine and often private nature continues to make it unpaid or underpaid and little recognized. For migrant workers who find themselves at the bottom of the carework sector hierarchy, working as babysitters, domestic workers and low-rank nurses, their body work remains largely hidden, is perceived as dirty, and experienced as precarious labour (McDowell, 2015).

${ }^{6}$ Perhaps this is not surprising given the language of 'oppression' of the classic intersectional approaches that paved the way for discussions of bodies and embodiment. However, some intersectional approaches are starting to shift from 'oppression' to 'diversity' (Bürkner, 2012: 182). Studies that focus on the intersectional privileges of highly skilled migrants (Bastia, 2014) may be considered an example of this tendency.
} 
relationships, and belief systems' (Iskander et al., 2010: 1598). In tandem with their use of other resources like material assets and social networks, migrants can make use of bodies and bodily aspects to adhere to foreign norms, thereby providing a basis for migrant differentiation (Erel, 2010).

However, a recognition of migrant bodies as potential resources should not ignore the vulnerabilities that deploying these resources may entail. In this regard, and referring to the second strategy mentioned above, it is key that mobile or migration-specific embodied capital is formed transnationally (Erel, 2010; Kelly and Lusis, 2006), and that migrants' embodied social positionings should be viewed from a 'multi-scalar' (Mahler et al., 2015) or 'translocational' (Anthias, 2012; 2016) perspective. The multi-dimensional, embodied social positionings that migrants experience vary across time and place, and therefore need to be 'located' (Anthias, 2012; 2016; Sinatti, 2014; Silvey, 2005). ${ }^{7}$ It follows that these positionings may be contradictory, subject to change, and particularly, that they get re-negotiated by moving across borders (Bastia, 2014). By virtue of their migration, the environment in which the research participants operate becomes translocalised: different social and geographical locations intervene and affect the relative importance of migrants' resources and positioning in light of their migration trajectories (Erel, 2010; Kelly and Lusis, 2006). The call for including multiple social and geographical locations is gaining ground in intersectional analysis of migrant experiences (Anthias, 2012; Mahler and Pessar, 2001; Mahler et al., 2015; Ryburn, 2016) and encourages an exploration of how migrants may appropriate their bodies by making use of multiple contexts simultaneously.

\section{Methodological considerations}

This paper's case for migrant embodied practice and divergent trajectories builds on empirical material from more than five years of multi-sited, multi-method ethnographic research, including a

\footnotetext{
${ }^{7}$ See also Guarnizo and Smith, 1998, for a discussion of the necessary 'localisation' of transnational practices.
} 
little over seven months of face-to-face fieldwork, with at its core 26 migrant families from the Nicaraguan village of Muy Muy and their family members in Costa Rica and Spain (see Winters, 2016). Inspired by discussions on multi-sited fieldwork (Marcus, 1995; see also Falzón, 2009), I tried to follow the connections to people and places that would enable an in-depth view of the diversity of migrations Muy Muy families engage in (Winters, 2016). 'Following' these families across time and space, sometimes literally and at other times via telephone, allowed me to gain insight into the social and geographical locations that shaped their migration experiences. The fieldwork in Muy Muy (2009-2014) involved sustained contact and observations/interviews with multiple members of the 26 core families, but also included other individuals (such as shop owners and money lenders), resulting in a total of 93 participants. The fieldwork in Costa Rica (2011) took place in five locations and involved visits and interviews with fourteen male and female migrants, belonging to nine different families that were part of the 26 core families in Muy Muy. In addition, I conducted interviews with five male and female members of Costa Rica's academic and business community. Although the focus in this paper is on female Nicaraguan research participants in Seville, their accounts will be complemented and strengthened with observations and interviews from Muy Muy and Costa Rica, to reflect the translocal character of their families. ${ }^{8}$

The fieldwork in Spain (2012) involved visits and interviews with nine migrants (eight female and one male) at their sites of work, home and leisure in the metropolitan area of Seville, which included the city of Seville and its neighbouring towns San Juan de Aznalfarache and Coria del Rio. The majority of the research participants in Seville were in their twenties or thirties, from relatively well-to-do Muy Muy families, and employed in the domestic care sector at the time of research. The interviews focused on migration histories; future plans for migration and/or livelihood in Muy Muy; and daily life in Seville, including employment experiences, social networks, and relationships with Spaniards. The

\footnotetext{
${ }^{8}$ Whenever I use research material from Muy Muy or Costa Rica instead of Spain, this will be clearly indicated.
} 
interviews were largely conducted informally, manually coded, and analysed based on an iterative back-and-forth process between theory and data from the broader ethnographic research.

In the analysis of this research material, the paper recognizes the well-established vulnerabilities of migrants who find themselves on the margins of Spanish society in terms of social, economic, and juridical status and protection (Domínguez-Mujica et al., 2012). However, the paper does not a priori assume migrants' marginalization but rather, through a focus on embodied practice, zooms in on the ways in which migrants deal with the obstacles and opportunities they encounter. This way, the paper intends to give due account of migrant agency, including their imagining about and planning for the future in dialogue with their positioning in the social hierarchies of multiple contexts (Mahler and Pessar, 2001: 447). For analytical purposes, I have distinguished between three interrelated key areas of embodied practice that emerge in the course of the research participants' trajectories: passing for a tourist; enduring difficult circumstances in Spain; and appropriating feminine and ethnic identifications and positionings. With 'appropriating' I refer to - for lack of a better term - 'owning' one's body, or the active but not necessarily conscious or strategic utilization of one's body and bodily aspects in specific phases of migration.

\section{A sketch of Nicaraguan migration to Spain}

In Nicaragua, unemployment and underemployment contribute to a reserve of 'cheap mobile labour' that serves neoliberal interests and constitutes a core component of Central America's current insertion in the global economy (Robinson, 2003). Nicaraguan migrations also represent an intensification and diversification of traditional trajectories that build on regional inequalities and interdependencies (Morales Gamboa, 2007; see also Hamilton and Stoltz Chinchilla, 1991). These include the growth of agro-export, industrialization and infrastructure, as well as intensified displacements due to socio-economic crises and conflicts during the 1980s, and the consolidation of regional labour transnationalization during the 1990s. Newer migration dynamics include shifts in 
gender and class relations (Sandoval-García, 2013) as well as upcoming destinations, Spain in particular (OIM, 2013). In general terms, and without counting Nicaragua's significant internal and informal migration (Morales Gamboa, 2007), an estimated 13\% of Nicaraguans lives and works abroad, mostly in Costa Rica, the United States, Spain, Honduras and Panamá (OIM, 2013). A considerable share of these migrants sends remittances, mostly from the United States, Costa Rica, and Spain. On a macroeconomic level, these remittances have represented around $12-13 \%$ of Nicaragua's GDP in the last decade and, despite the most recent economic crisis, have remained relatively stable compared to other income sources.

Migration in Muy Muy, Central Nicaragua, fits these broader migration dynamics and the importance of remittances for many households. Although Muy Muy is part of a cattle-raising territory increasingly integrated into lucrative global value chains of milk and meat, the majority of its 15,000 strong population can only marginally benefit from these chains and continues to rely on migration for their livelihoods (Grigsby Vado and Pérez, 2009; Steel et al., 2011). My own fieldwork in Muy Muy found a diversity of migrations between but also within families, mostly to Costa Rica but also to the United States and including the relatively new phenomenon of (female) migration to Spain (Winters, 2016). In brief terms, Costa Rica represents a relatively accessible, frequently temporal and informal migration option, often for migrants with low levels of schooling, an increasing proportion of whom are female, and who are employed in agriculture, construction and the (personal) services sector (Baumeister, 2006). In contrast, US-bound migrants tend to have more financial and educational resources but their options for circulating have become increasingly limited and reinforced these Nicaraguans' tradition of staying more permanently. Simultaneously, the increased difficulty for USbound migration and the rapid multiplying of transnational networks facilitated a tenfold growth in Nicaraguan migration to Spain between 2005 and 2010 (González Miranda, 2011). According to the Spanish National Institute of Statistics (INE), this growth continues. For example, in 2017 there were 
more than 26,000 Nicaraguans in Spain, compared to almost 17,500 in $2012 .{ }^{9}$ In Seville, the number of Nicaraguans went up from a little over 1,000 in 2012 to approximately 2,000 in 2017.

In both Seville and Spain as a whole, Nicaraguan migrants are predominantly female and relatively young. Since the 1990s, a number of dynamics converged to create a Spanish labour market attractive for migrants, particularly women: the country's expanding economy, comparatively porous borders, relative lack of state intervention, large informal economy, growing female labour market participation, population ageing, and a substantial domestic employment sector (Escriva and Skinner, 2008; León, 2010). Male migrants often found employment in the booming construction sector. Migrant labour in Spain was further marked by 'Latin-Americanization' and, despite a number of regularizations, by 'irregular' forms of employment (see also Mas Giralt, 2017). Since 2008, the global economic crisis has severely yet unevenly affected the Spanish labour market (Domínguez-Mujica et al., 2012), sharply decreasing formal employment (particularly in the construction sector) while increasing informal work. One of the ways in which the increased precarity of employment was highly visible in Seville in August 2012, was through the many announcements on paper, pasted to lampposts and walls, with which people offered their labour power (see figure 1). Although the crisis disproportionally affected male migrants and urged the Spanish government to tighten immigration permits and encourage voluntary return, the Spanish labour market has remained attractive for female Nicaraguan migrants. They have continued to find employment, mainly in the ever-expanding but largely informal domestic employment sector.

\footnotetext{
${ }^{9}$ These numbers should be used with caution given the difficulty of measuring irregular forms of migration. Calculated in March 2018 via the website of the Instituto Nacional de Estadística (INE), section Demografía y Población: www.ine.es/dyngs/INEbase/listaoperaciones.htm
} 


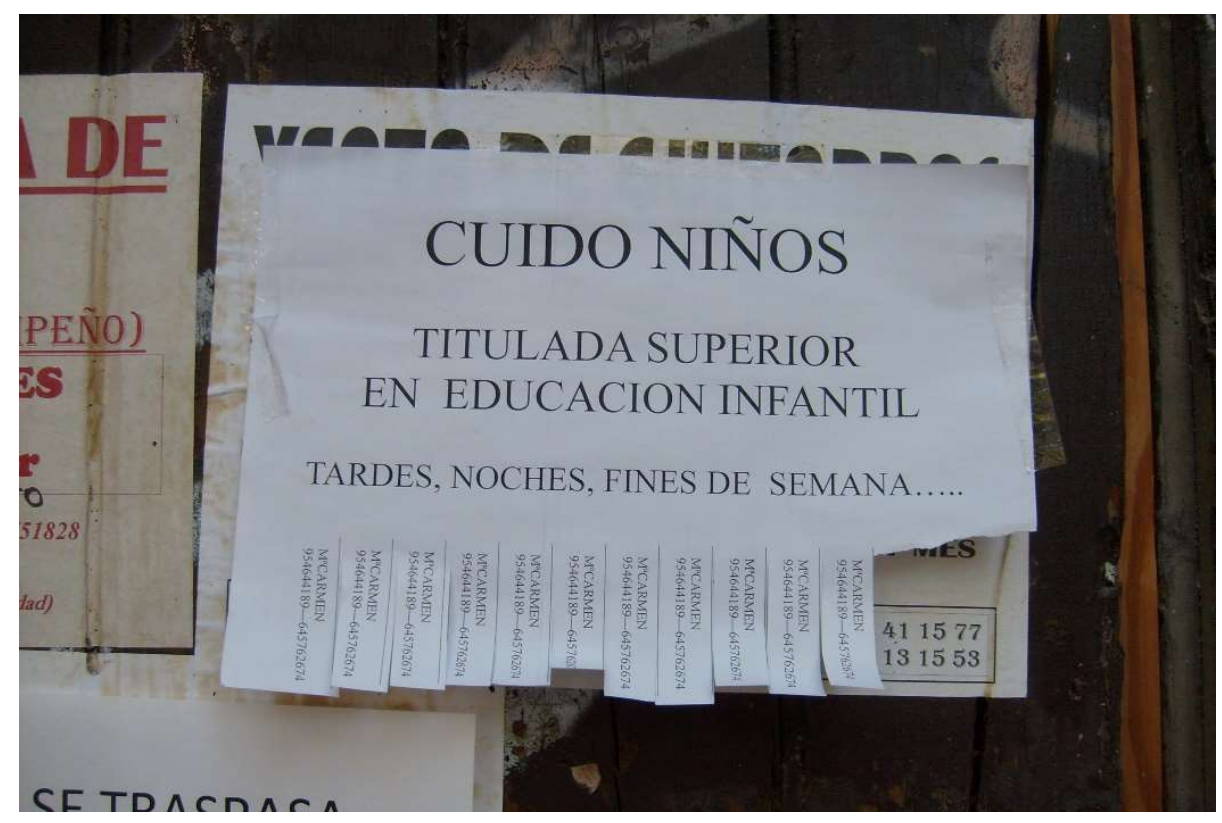

Figure 1. Public job hunting. One of the many announcements put up in the streets of Seville. Loosely translated, this one reads: I babysit children / I have a degree in pre-school education / Afternoons, nights, weekends... (Photo by author, August 2012).

The female Nicaraguan research participants in Seville come from families with above-average financial and material assets. Still, they cite finding a job and earning money as primary reasons for their migration, in order to repay debts (including those involved with their migration), to save, to ensure quality housing and schooling for their children, and to set-up entrepreneurial activities (Winters, 2016). Although their reasons for migrating are multiple, and extend to adventure and escape, these tangible goals and investments are classic examples of migration gains and may serve to make migrants' migration more socially acceptable in the eyes of their family members. In addition, their intercontinental journey requires significant funds. These funds usually come from their families' savings or asset-based loan opportunities and need to be paid back. Migrants and their families also tend to expect higher monetary rewards from migrating to Spain compared to other destinations (like Costa Rica), considering the greater sacrifices, for example, in terms of lengthy family separation. Hence, in the following elaboration of passing, enduring and appropriating, the need for jobs and money resurfaces. 


\section{Three key areas of embodied practice}

\subsection{Passing for a tourist (and hiding your identity of unauthorized migrant worker)}

Testifying to the inequalities of global mobility, the way in which the research participants attempt to cross into Spain hinges on whether they are able to convince authorities that they belong in the tourist category. In order to hide their intent to work (which they are not allowed to do) and pass for a tourist, it is not only common to make a detour on their way to Spain but also to invest in appearance and presentation. These elements culminate in a performance of border crossing that may include new clothing and a fresh haircut as well as money. For example, Carmen (late twenties), a mother of two young children who had already migrated to Spain before, said she would need money to 'arreglarse para verse como turista' [get fixed up to look like a tourist] before leaving for Spain again (interview 28 September 2011, in Muy Muy). In addition, she would need sufficient funds to show she is capable of financing her visit and other proof such a return ticket and hotel reservation in order to pass for a tourist. Angela (late twenties), who borrowed the funds for this purpose from a sister who was already in Spain, deemed these funds necessary 'para presentarse' ([to present oneself in front of migration authorities], interview 4 August 2012). The confidence of these material resources, coupled with the way you look and behave, is part of the embodied performance of crossing borders without attracting unwanted attention. Migrants learn how to perform from each other, from migration facilitators, and even, as Khosravi (2010) mentions, from the media.

Nevertheless, a migrant's performance does not guarantee a successful border-crossing, as this also depends on, amongst others, locally-specific migration dynamics and policy priorities at a particular time (see also Coplan, 2012). Carmen told me how one of her nieces had failed on her first attempt to enter Spain via Portugal, but succeeded about seven months later, via France. According to Carmen, on her second try her niece had benefitted from the 'movimiento' [holiday movement, 
hustle and bustle] in December (interviews 7 October 2010 and 4 February 2011, in Muy Muy). Moreover, the control of migrants' border crossings is no longer restricted to one demarcated nation-state limit, as the literature on the externalisation of borders indicates (Casas-Cortes et al., 2015). Increased migration control within nation-state territories makes it more difficult for migrants to overstay entry visas (Abraham and van Schendel, 2005) and to engage in paid employment. In Spain, the research participants arrived on a tourist visa, which is valid for three months, and afterwards lived and worked without the required documents (although they may have been registered in a Spanish municipality). Based on a condition called 'arraigo social', ${ }^{10}$ which typically requires an employment contract, they may obtain temporary residency after three years, which they may eventually use for nationalization (El Nuevo Diario, 2013). In the meantime, their bodies are under scrutiny and become targets for deportation.

However, migration control beyond territorial borders did not seem a pressing issue among the research participants in Spain. This was exemplified by Angela, who had arrived via Italy in 2009 and overstayed her entry visa, yet appeared at ease showing me around a number of tourist sites in Seville. Our first acquaintance took place in a public park, after which we went on foot to a bar, by bus to the Plaza de España (where she insisted on taking pictures), and on foot again to the Cathedral and the Giralda watch-tower. While we were waiting for the bus we were seated in front of the local police office. And when we walked around we passed special police units who were charged with ID inspection. When I asked Angela if she was not afraid, given that she lacked the correct documentation, she said, 'con miedo uno no se siente mejor' ([being afraid doesn't make you feel better], visit 31 July 2012). Angela's rather carefree attitude towards migration control was shared by the other research participants.

10 “Es una autorización de residencia temporal por circunstancias excepcionales que se podrá conceder a ciudadanos extranjeros que se hallen en España y, o bien tengan vínculos familiares en España o estén integrados socialmente." Retrieved 21 August 2015 from http://extranjeros.empleo.gob.es/es/ informacioninteres/informacionprocedimientos/Ciudadanosnocomunitarios/hoja036/index.html 
In hindsight, there may have been several reasons for this attitude: Angela may have extended her performance as a tourist with me, perhaps feeling relatively safe next to a Northern Europeanlooking woman, and at the specific time and place of research there may have been a low intensity of migration control. Still, the research participants in Spain (as well as those in Costa Rica) also feel relatively safe as long as they avoid 'vagar', a common term used to denote a range of negative public behaviour, from hanging around, making noise and being drunk to committing petty crime (Winters, 2016). The avoidance of 'vagar' may be most urgent for (young) Nicaraguan men, who may be used to a flamboyant, aggressive type of behaviour more likely to catch the eye of migration authorities (see Hirsch, 1999). For example, Angela's brother-in-law Iván (late twenties) told me how local police stopped him once, when he took a shortcut home via a zone with 'muchos vagos'. Iván told the police that he did not carry his ID, and that he was in a hurry to pick up his daughter. The police told him to make sure to carry his ID next time and let him pass (visit 3 August 2012). It is noteworthy that in the face of migration authorities Iván distanced himself from 'vagar' by embodying his paternal, caring role. In the following sections I will go deeper into the research participants' gendered, and racialized, social positionings in Spanish society.

\subsection{Enduring difficult working and living conditions (and enjoying freedom of movement)}

The female research participants in Spain all work in informal domestic employment, taking care of households, children and the elderly. In our conversations, they put emphasis on the ability to endure the difficult working and living conditions that this type of migration and labour involves. Although they often have some work experience before coming to Spain, at their family farm, a shop in Muy Muy, or the free trade zone in Managua, they generally do not have any experience in the physically and emotionally demanding (live-in) paid carework sector. In Spain, they not only deal with heavy, underpaid and insecure labour but also with less than ideal housing, either in cramped, overpriced apartments or with their employers, both of which quite literally minimises their bodily space. For example, Angela's sister Blanca (early twenties) said that she suffered at first, when she had just 
arrived. With no previous experience in paid carework, Blanca had to take care of an elderly woman who lived in an isolated village and, according to Blanca, was rude and weepy. In time, however, Blanca got used to employers' diverse demands. At the time of our interview she even worked as an 'interna', a live-in caretaker, which is generally considered to be a very demanding job arrangement. However, like the other research participants, Blanca stressed she has to 'aguantar' [endure] the day-to-day suffering that her migration and labour entails (interview 8 August 2012).

The suffering of migrants as well as their family members 'at home' was often expressed in terms of bodily sensations, including high blood pressure (Carmen), crying (Angela and her dad in Muy Muy), and eating (Angela and Blanca). However, the research participants also indicated that such suffering and the enduring it requires is but one aspect of their migration. The specific experience of live-in caretakers provides an example of how a potential area of suffering can also become one of opportunity to enjoy new freedoms. On the one hand, this niche occupation for female Nicaraguan migrants reduces opportunities for socializing. To Erica (early twenties), who came to Spain after her older sister, working and living in the same house makes her feel like 'un pájaro en jaula' ([a bird in a cage], interview 13 August 2012). Employers' expectation for one to be (nearly) always on call severely curtails the freedom of movement of live-in caretakers. This was highly visible when I visited Flor (late twenties), who left two children with their father in Muy Muy and who worked in Costa Rica before coming to Spain. Flor could not guide me very well to her employer's apartment because she only seemed to know a nearby park and supermarket. She could come down from the apartment to the supermarket to get me, but she could not go further than one block, because her employer's daughter lived close-by and may see her. When I finally found her after several phone calls, Flor commented that although she finishes at 5PM, she always has to be 'pendiente' [attentive] and cannot go away too far if she wants to avoid giving the daughter motive to complain (interview 22 August 2012). 
On the other hand, having a live-in caretaker job in Spain also provides a certain degree of freedom that Muy Muy generally does not provide. Carmen's niece Raquel (early thirties) expressed this ambivalence when we went for a drink in the Macarena neighbourhood, where many migrants live and socialise. Based on previous research experience, I mentioned to Raquel that in Muy Muy women don't usually go to a bar. Local constructions of (decent) femininity assume that women stay at home, with their families, and that women who go to a bar must be prostitutes. Raquel responded that the ability to move around more freely was exactly the reason she would like to stay in Spain a while longer. 'I like the freedom here, you can do whatever you want. I don't like to be 'encerrada' [locked in] the whole day' (interview 15 August 2012). Whereas being employed in the carework sector means that their migration represents a certain continuation of supposedly feminine duties and tasks (McDowell, 1999; see also the next section), by border crossing into this particular Spanish context the research participants also encounter and enjoy other norms of how women can and should behave. In terms of bodily movement across public and private domains, this type of migration and labour may thus make the research participants feel both more 'caged' and more free at the same time. ${ }^{11}$

\subsection{Appropriating feminine and ethnic identifications and positionings}

Relatively young, able-bodied Nicaraguan women can act on their femininity and supposedly 'caring nature' (McDowell, 1999) for doing the type of docile body work that is central to the domestic carework sector (McDowell, 2015). Given this perception and their upbringing, which indeed includes the lion share of day-to-day carework (Winters, 2014), Nicaraguan females hold an advantage over their male counterparts who are usually not considered for this type of work. Blanca, for example, told me how difficult it was for her husband Iván to find employment beyond the occasional day job,

\footnotetext{
${ }^{11}$ In addition, working within such a private space as the home may, to a certain degree, 'shield' the research participants from unwanted public attention based on their appearance as migrants, but also 'expose' them to the risk of harassment that is hidden from the public eye.
} 
and when he suggested he could take Blanca's night shift, looking after an elderly lady, the lady declined because she did not want a man to take care of her (interview 8 August 2012). However, this particular feminine 'asset' in the labour market cannot be taken for granted; a 'docile, caring nature' needs to be appropriated. The research participants have not had any training in carework, and have to learn by doing, getting used to a wide variety of tasks. For example, Angela explained how taking care of an elderly lady means she has to clean, cook, shower her and get her dressed, and be attentive of her needs at all times (interview 4 August 2012). Female migrants are expected to have been inculcated 'at home', or to be able to develop, the skills necessary for the comforting and cleaning aspects of carework in the global labour market. ${ }^{12}$ Their bodies are thus constructed as appropriate for this kind of work (McDowell, 2008: 499).

The 'predisposition' for caretaking of these female migrants is further reinforced by their ethnic Latina identity. Although the research participants may act on their (perceived) cultural closeness to Spanish families, in language and often religion, they can also distinguish themselves positively from Spanish sons and daughters who, according to them, do not care about their elderly parents but just about their inheritance. Raquel, for example, told me how the children of the elderly lady she takes care of live nearby, but they hardly ever visit her. 'Sometimes I have to go to them to ask them to come over and they say 'que cruz' [what a cross to bear]'. Not unlike the other research participants, Raquel 'hears this all the time' and that is why she insists that in Spain 'children don't love their parents. In Nicaragua it's different, your mother will always be your mother. You don't put her in a nursing home when you don't want to see her anymore' (interview 15 August 2012). In contrast, by 'being there', which is body work par excellence, the research participants appropriate specific aspects of their ethnic identity and thereby uphold their employment. Although context-specific gendered and racialized expectations, including their often insecure migration status, positions the

\footnotetext{
${ }^{12}$ In addition, the female research participants' 'docile, caring nature' may be linked to an insecure migration status which reinforces their perceived ability and willingness to perform private, docile body work.
} 
research participants as relatively vulnerable subjects in global labour and migration regimes, they make the most of their embodied positioning to safeguard their job, earnings, and perhaps even an improvement in their working and living conditions.

In addition to appropriating the socially defined feminine and ethnic aspects of their bodies through body work, the research participants also make use of bodily circulation within their social network (see also Marchetti, 2013). This can be seen in the practice of lending one's labour power to fill work shifts of others, enabling them to do chores and look for better jobs, or in the practice of asking potential future migrants to come work in Spain (an option which of course depends their relationship with employers, see Escriva and Skinner, 2008). Established migrants can invite or accept friends and family members to join them, 'borrowing their bodies' to share jobs and housing and spread monetary risks. For example, when Blanca got pregnant while in Spain, she lent her motherin-law money to migrate, hoping to receive steady income from repayment of that loan when her pregnancy would inhibit her to work (interview 8 August 2012). After her baby girl was born, Blanca also invited her older sister Angela to help take care of the baby, and to fill the night shift of her thendomestic employment. At the time of our interview, Blanca considered (and eventually did) 'bring' another sister to take over her day shift because she had found a new job. Conveniently, both sisters would share in the cost of Blanca's apartment as well. ${ }^{13}$ Crucially, this type of cross-border bodily circulation further highlights the appropriateness of particular bodies.

\section{Bodies as sites of struggle: agency, differentiation and translocal embodiment}

As becomes clear from the empirical material presented here, migrant bodies play a key role in migration trajectories, but they are more than stigmatised, restricted and mistreated: even those bodies that resemble the proverbial bird in the (domestic) cage may experience room for

\footnotetext{
${ }^{13}$ When working as a live-in caretaker, migrants still need a place to go during days off, a place that can also serve as a (temporary) back-up when they lose or leave their job.
} 
manoeuvre. That is, migrant bodies can also be considered as resources of migration-specific or mobile embodied cultural capital (Erel, 2010; Kelly and Lusis, 2006) to initiate, endure, and improve trajectories. For example, the Nicaraguan research participants act on bodily stereotypes of 'docile, caring' femininity and ethnic 'dedication to family' to access and perform employment in elderly care. In tandem with other resources like social networks, migrants can make use of bodies and bodily aspects to adhere to foreign norms and thereby actively shape their trajectories.

The importance of migrants' embodied cultural capital in adhering to foreign norms also means their bodies, and the scope for performance they provide, constitute a basis for migrant differentiation and divergent trajectories. At the time of research, specific Spanish labour market characteristics and migration regulations, as well as evolving transnational networks and local perceptions of Nicaraguans, converged to a preference for a specific type of migrant, thereby shaping migrant trajectories. This extended to differentiation in migration decision-making, where the requisites of expected future body work in Spain 'made' Nicaraguan men less eligible for migrating. In Muy Muy it was common to hear that almost only females migrate to Spain because for males employment is scarce. Gricelda (early thirties), who came to Spain with Erica's niece, told me her brothers wanted to join her in Seville but she was very reluctant to support their migration. Like the other research participants, she commented that 'aquí no hay [trabajo] para hombres' ([here, there is no work for men], interview 13 August 2012). ${ }^{14}$ This way, specific bodies and their socially defined aspects (such as males and their perceived lesser ability to care) become a basis for differentiation in access to migration in Nicaragua.

Migrants' use of embodied cultural capital is part of a learning process of foreign norms that further differentiates migrants in their quest for finding a job and earning money. Some migrants are better

\footnotetext{
${ }^{14}$ Although this is not my focus here, it is likely that Gricelda, and other female Nicaraguan migrants, also dreaded the idea of having male family members around, as they may curtail their relative freedom. By keeping up the image of Spain as a country where there is no work for men, they become migration gatekeepers.
} 
able than others to do so, and can thereby positively influence the success of current migration and the possibilities of future migration. In Costa Rica, for example, the research participants attributed a certain level of job security to their skill to 'please employers', which includes not being overly assertive or 'respondón' ([cheeky]; Winters, 2016). One of the research participants here, Cedro (late thirties) told me his wife does not last in her Costa Rican jobs because 'maybe she is very direct ... or she is very talkative and maybe not everyone can deal with that' (interview 4 March 2011, in Costa Rica). In contrast, Carmen described that the family of the elderly couple that she took good care of in Spain are still very fond of her and that she can count on them for any help she may need whenever she decides to migrate again (interviews 27 January and 7 October 2010, in Muy Muy). These opposing examples show how migrants' embodied cultural capital affects their ability to forge solid relationships that can help them throughout their trajectories.

Migrant bodies and embodied practices cannot be reduced to embodied cultural capital. Nevertheless, throughout the trajectories of female Nicaraguan migrants in Spain, their embodiment does gain such strategic meaning. As socially defined 'others', employed in the highly 'bodily' carework sector and with few alternative resources at their disposal, their migrant bodies become crucial sites of struggle for access to migration, jobs, and overall improvement of their trajectories (see also Schmoll, 2014). The way in which they make use of their body to present themselves and to capitalize on a certain image plays a key role in their trajectories. When their embodied performance enables them to cross and circumvent international borders, they re-position the inequalities of global mobility regimes (Glick Schiller and Salazar, 2013). And when they act on their femininity and ethnicity to 'win over' employers (Tamagno, 2002), they appropriate bodily aspects that in other contexts may serve as the basis for their exclusion.

Defying migration regulations, as well as working to 'please' and 'win over' employers also makes the research participants vulnerable for exploitation as it does not contest but rather reproduces global hierarchies. However, following transnational (Kelly and Lusis, 2006), 'translocational' (Anthias, 2012; 
2016) and multi-scalar (Mahler et al., 2015) perspectives, by virtue of their migration the environment in which the research participants operate becomes translocalised: different social and geographical locations intervene and affect the importance of migrants' resources and positioning in light of their trajectories. For example, degrading work conditions in Spain are rationalised against much-needed earnings for the family. Although the research participants recognise the exploitative tendencies of their job and their dependence on the good will of their employers and their employers' children, they see this temporary suffering in light of their even more restricted opportunities in Nicaragua, and in light of what they can achieve for their livelihoods 'at home'. Crossing borders means that migrants encounter new or reinforced social inequalities, but looking at these simultaneously shows that not all these inequalities have equal weight. Current marginalization abroad and (expected) privilege at home may exist side by side (Mahler, 2015, see also Nash, 2008: 10).

An empirical example that demonstrates the importance of not only taking into account different locations when looking at migrants' embodied practices and positionings, but also the role of time (Anthias, 2016), concerns paperwork. According to the research participants in Spain, obtaining the correct documentation to live and work in Spain is not primarily geared towards building a permanent future there, but towards increasing mobility. ${ }^{15}$ For example, Erica expressed the desire to travel to the United States to be closer to her family in Nicaragua. Through her good contacts from past caretaking employment, she hoped to obtain her Spanish residency so she could apply for a visa to the United States (interview 13 August 2012). Such paperwork not only helps the research participants with jobs and housing in Spain, but it also enables migrants to visit home, to return to Spain, and/or to move onwards, expanding their trajectories (see also Mas Giralt, 2017). A

\footnotetext{
${ }^{15}$ Or at least: the option of increased mobility, see the discussion of mobility capital by Moret (2018).
} 
recognition of migrants' translocal embodied practices and positionings and the different social and geographical locations these involve thus helps to understand ever-evolving trajectories.

Such a translocal perspective underlines the view that migrant bodies and embodied practices need to be seen as emplaced in specific (but not static) environments (Dunn, 2010; Pink, 2011). The term translocal seems to be particularly appropriate to describe their experience because it emphasizes both the cross-border and the locally-specific characteristics of migration (Anthias, 2016: 186; see also Guarnizo and Smith, 1998). It follows that the extent to which migrants are able to make use of their bodies and bodily aspects depends, amongst others, on the specific systems of categorization, facilitation and control that have been established between specific localities 'at home' and 'abroad'. Crossing other borders, and working and living elsewhere at other times, places migrants in other matrices of gendered, racialized, and generational positionings and may require other embodied practices. By looking at migrants' bodies as key sites of struggle, and the ways in which they appropriate these in distinct yet interconnected contexts, we can appreciate how migrant bodies not only play a key role in shaping trajectories, but also in 'anchoring' these. This is because migrant bodies cannot be viewed in isolation: they inhabit and connect the social and geographical locations of migrant trajectories, including family decision-making, access to workplaces, and the development and deployment of embodied cultural capital. Focusing on thus situated migrant bodies helps to avoid a too simplistic, disconnected notion of migrant mobility. In the words of Dunn (2010: 7), 'so long as the scale of analysis is at the level of bodies, it is unlikely that ... emphasis will swing too far towards mobility, and too far from place'.

\section{Conclusion}

This paper has foregrounded embodiment to advance our understanding of the mobility politics that shape divergent migrant trajectories. By distinguishing passing/hiding, enduring/enjoying, and appropriating, three interrelated key areas of embodied practice that were part of the trajectories of 
female Nicaraguan migrants, the paper demonstrated how specific migrant bodies and bodily aspects that often evoke images of victimhood can also be considered as resources if seen from a translocal embodiment perspective. A recognition of migrants' embodied practices and positionings across multiple social and geographical locations challenges common simplifications of migrant bodies, female 'body working' bodies especially, as the 'caged victims' of global, neoliberal dynamics. Moreover, highlighting migrants' embodied cultural capital also shows how their bodies, the scope for bodily performance and the capacity for embodied learning, constitute a basis for migrant differentiation based on gender, ethnicity, and other axes of difference. Migrant bodies thus add an essential layer of complexity and relationality to the mobility politics that shape migrant trajectories.

Viewing migrant bodies and bodily aspects as resources does not equal an underestimating of possible marginalization. Although access to mobility can be considered an asset, migration should not be equated with liberation and enhanced opportunity per se, given the disparate power relations and possible costs and sacrifices for migrants and others involved (Vaiou, 2012). However, it is precisely by including different social and geographical locations that there is room for acknowledging experiences of exploitation and empowerment simultaneously, as well as for uncovering ways in which social inequalities may someday be transformed (Anthias, 2012: 108). An example in this regard concerns the power that the female Nicaraguan research participants can exert in their families' migration decision-making. Their own employment experience and earnings in Spain have gained them a certain level of authority to influence the perception of family members and the choice of who will migrate next, when and where to. They may thus be better positioned in the politics of mobility than they were before, especially vis-a-vis their male relatives in Muy Muy (see also Winters, 2014). A focus on migrant embodiment thus constitutes a promising avenue for well-rounded accounts of complex migrant agency and the ways in which it is entangled with multiple people and places. 
The paper showed that bodies can be seen as a multi-faceted, non-erasable component of contextspecific struggles over mobility. This way, the paper hopes to inspire methodological and empirical avenues for future research. First, by showing the value of multi-sited research in following migrant trajectories, while at the same time acknowledging the importance of taking into account the specific localities that shape experiences of embodiment, negotiation and differentiation. Second, by highlighting the need for more attention to simultaneously interlocking axes of difference. The empirical research in this paper has highlighted the feminine and ethnic aspects of embodiment among a particular group of Nicaraguans in Spain, but what about, for instance, elderly migrants? How do their age and generational identification and positioning contribute to shaping their own and others' trajectories? Third, given that bodies and their representations and performances are socially shaped, other actors of migration settings need to be taken into account. For example, although workplaces are recognized as important sites for looking at migrant bodies as 'lived sites of power' (Silvey, 2005: 144), in analyses of the carework sector the clients of body work are still largely missing (McDowell, 2015; for an exception see Marchetti, 2013). These actors, as well as settings beyond carework, would provide interesting avenues of future research in order to further assess the potential of a translocal embodiment perspective for understanding divergent migrant trajectories, and the politics of mobility that shape these.

\section{Acknowledgements}

I would like to thank the participants of the workshop Re-Routing Migration Geographies: Migrants, Trajectories and Mobility Regimes, in particular Joëlle Moret, Griet Steel, Ilse van Liempt and Catherina Wilson, as well as an anonymous reviewer, for their useful feedback on earlier drafts of this paper. I also wish to thank all the research participants for generously and patiently sharing their experiences over many years of research. Funding: This work was supported by the Institute of Development Policy and Management (IOB) Research Fund and the University of Antwerp Doctoral School. 


\section{Bibliography}

Abraham, I. and W. van Schendel (2005) Introduction. The Making of Illicitness. In W. van Schendel and I. Abraham (eds.) Illicit Flows and Criminal Things: States, Borders, and the Other Side of Globalization. Bloomington: Indiana University Press, pp. 1-37.

Amelina, A. and T. Faist (2012) De-naturalizing the national in research methodologies: key concepts of transnational studies in migration. Ethnic and Racial Studies 35 (10): 1707-1724.

Anderson, B. and I. Shutes (2014) Migration and Care Labour. Theory, Policy and Politics. London: Palgrave Macmillan.

Anthias, F. (2016) Interconnecting boundaries of identity and belonging and hierarchy-making within transnational mobility studies: Framing inequalities. Current Sociology Monograph 64 (2): 172-190.

Anthias, F. (2012) Transnational mobilities, migration research and intersectionality. Towards a translocational frame. Nordic Journal of Migration Research 2 (2): 102-110.

Bastia, T. (2014) Intersectionality, migration and development. Progress in Development Studies 14 (3): 237-248.

Bastia, T., N. Piper and M. Prieto (2011) Guest editorial. Geographies of migration, geographies of justice? Feminism, intersectionality, and rights. Environment and Planning A 43: 1492-1498.

Baumeister, E. (2006) Migración internacional y desarrollo en Nicaragua. Serie población y desarrollo \#67. Santiago de Chile: Naciones Unidas/CEPAL.

Bilge, S. (2013). Intersectionality Undone. Saving Intersectionality from Feminist Intersectionality Studies. Du Bois Review 10 (2): 405-424. 
Blunt, A. (2007) Cultural geographies of migration: mobility, transnationality and diaspora. Progress in Human Geography 31 (5): 684-694.

Buckley, M., S. McPhee and B. Rogaly (2017) Labour geographies on the move: Migration, migrant status and work in the 21st century. Geoforum 78: 153-158.

Bürkner, H.-J. (2012) Intersectionality: How Gender Studies Might Inspire the Analysis of Social Inequality among Migrants. Population, Space and Place 18: 181-195.

Carling, J. (2014) Scripting Remittances: Making Sense of Money Transfers in Transnational Relationships. International Migration Review 48 (S1): S218-S262.

Carling, J. (2002) Migration in the age of involuntary immobility: Theoretical reflections and Cape Verdean experiences. Journal of Ethnic and Migration Studies 28 (1): 5-42.

Casas-Cortes, M., S. Cobarrubias and J. Pickles (2015) Riding Routes and Itinerant Borders: Autonomy of Migration and Border Externalization. Antipode 47 (4): 894-914.

Connell, J. (2008) Niue: Embracing a Culture of Migration. Journal of Ethnic and Migration Studies 34 (6): 1021-1040.

Coplan, D.B. (2012) Border Show Business and Performing States. In T.M. Wilson and H. Donnan (eds.) A Companion to Border Studies, First Edition. Chichester: Wiley-Blackwell, pp. 507-521.

Cresswell, T. (2010) Towards a politics of mobility. Environment and Planning D: Society and Space 28: $17-31$. 
Domínguez-Mujica, J., R. Guerra-Talavera and J.M. Parreño-Castellano (2012) Migration to Spain. Migration at a Time of Global Economic Crisis: The Situation in Spain. International Migration 52 (6): pp. $113-127$.

Dyer, S., L. McDowell and A. Batnitzky (2008) Emotional labour/body work: The caring labours of migrants in the UK's National Health Service. Geoforum 39: 2030-2038.

Dunn, K. (2010) Guest Editorial. Embodied Transnationalism: Bodies in Transnational Spaces. Population, Space and Place 16: 1-9.

El Nuevo Diario (2013) Crisis en España no frena migración nica. 12 August 2013. Retrieved 28 July 2015 from www.elnuevodiario.com.ni/nacionales/294070-crisis-espana-no-frena-migracion-nica/

Erel, U. (2010) Migrating Cultural Capital: Bourdieu in Migration Studies. Sociology 44 (4): 642-660.

Escriva, A. and E. Skinner (2008) Domestic Work and Transnational Care Chains in Spain. In H. Lutz (ed) Migration and Domestic Work. A European Perspective on a Global Theme. Aldershot: Ashgate, pp. 113-126.

Falzon, M.A. (2009) Introduction. In M.A. Falzon (ed.) Multi-sited Ethnography: Theory, Praxis and Locality in Contemporary Research. Farnham: Ashgate, pp. 1-23.

Glick Schiller, N. and N. Salazar (2013) Regimes of Mobility Across the Globe. Journal of Ethnic and Migration Studies 39 (2): 183-200.

Glick Schiller, N. and P. Levitt (2006) Haven't We Heard This Somewhere Before? A Substantive View of Transnational Migration Studies by Way of a Reply to Waldinger and Fitzgerald. CMD Working 
Paper \#06-01. Princeton University: The Center for Migration and Development Working Paper Series.

González Miranda, J.L. (2011) Investigación exploratoria sobre migración de mujeres de Somoto (Nicaragua) a San Sebastián (España). Encuentro 90: 50-83.

Grigsby Vado, A. and F.J. Pérez (2009) Programa RuralStruc. Estrategias Campesinas frente a los efectos estructurales de la Globalización en la Agricultura y el Desarrollo Rural. Reporte de Segunda Fase. Managua: Instituto de Investigación y Desarrollo Nitlapan-UCA.

Guarnizo, L.E. and M.P. Smith (1998) The Locations of Transnationalism. In M.P. Smith and L.E. Guarnizo (eds) Transnationalism From Below. New Brunswick: Transaction Publishers, pp. 3-31.

Hamilton, N. and N. Stoltz Chinchilla (1991) Central American Migration: A Framework for Analysis. Latin American Research Review 26 (1): 75-110.

Herrera, G. (2013) Gender and International Migration: Contributions and Cross-Fertilizations. Annual Review of Sociology 39: 471-489.

Hirsch, J.S. (1999) En el Norte la Mujer Manda. Gender, Generation, and Geography in a Mexican Transnational Community. American Behavioral Scientist 42 (9): 1332-1349.

Hyndman, J. (2004) The (Geo)Politics of Gendered Mobility. In L.A. Staeheli, E. Kofman and L.J. Peake (eds.), Mapping Women, Making Politics. Feminist Perspectives on Political Geography. New York: Routledge, pp. 169-184.

Hyndman, J. (2012) The Geopolitics of Migration and Mobility. Geopolitics 17 (2): 243-255. 
Hochschild, A.R. (2000) Global Care Chains and Emotional Surplus Value. In W. Hutton and A. Giddens (eds.) On the Edge: Living with Global Capitalism. London: Jonathan Cape, pp. 130-146.

Hondagneu-Sotelo, P. (1994) Gendered Transitions. Mexican Experiences of Immigration. Berkeley: University of California Press.

Hui, A. (2016) The Boundaries of Interdisciplinary Fields: Temporalities Shaping the Past and Future of Dialogue between Migration and Mobilities Research. Mobilities 11 (1): 66-82.

Iskander, N., N. Lowe and C. Riordan (2010) The rise and fall of a micro-learning region: Mexican immigrants and construction in center-south Philadelphia. Environment and Planning A 42: 15951612.

Kelly, P. and Lusis, T. (2006) Migration and the transnational habitus: evidence from Canada and the Philippines. Environment and Planning A 38: 831-847.

Khosravi, S. (2010) 'Illegal' Traveller. An Auto-Ethnography of Borders. Palgrave Macmillan.

León, M. (2010) Migration and Care Work in Spain: The Domestic Sector Revisited. Social Policy and Society 9 (3): 409-418.

Mahler, S.J. and P.R. Pessar (2001) Gendered Geographies of Power: Analyzing Gender Across Transnational Spaces, Identities 7 (4): 441-459.

Mahler, S.J., M. Chaudhuri and V. Patil (2015) Scaling Intersectionality: Advancing Feminist Analysis of Transnational Families. Sex Roles 73: 100-112.

Marchetti, S. (2013) Dreaming Circularity? Eastern European Women and Job Sharing in Paid Home Care. Journal of Immigrant and Refugee Studies 11: 4: 347-363. 
Marcus, G.E. (1995) Ethnography in/of the World System: The Emergence of Multi-Sited Ethnography. Annual Review of Anthropology 24: 95-117.

Mas Giralt, R. (2017) Onward Migration as a Coping Strategy? Latin Americans Moving from Spain to the UK Post-2008. Population, Space and Place 23 (3): e2017. DOI: 10.1002/psp.2017.

Massey, D. (1993) Power-geometry and a progressive sense of place. In J. Bird, B. Curtis, T. Putnam and G. Robertson (eds.) Mapping the Futures: Local Cultures, Global Change. London: Routledge, pp. $59-69$.

McDowell, L. (1999) Gender, Identity and Place. Understanding Feminist Geographies. Minneapolis: University of Minnesota Press.

McDowell, L. (2008) Thinking through work: complex inequalities, constructions of difference and trans-national migrants. Progress in Human Geography 32 (4): 491-507.

McDowell, L. (2015) Roepke Lecture in Economic Geography-The Lives of Others: Body Work, the Production of Difference, and Labor Geographies. Economic Geography 91 (1): 1-23.

Merriman, P. (2017) Mobilities III: Arrivals. Progress in Human Geography 41 (3): 375-381.

Merriman, P. (2015) Mobilities I: Departures. Progress in Human Geography 39 (1): 87-95Morales Gamboa, A. (2007) La diáspora de la posguerra. Regionalismo de los migrantes y dinámicas territoriales en America Central. San José: FLACSO.

Moret, J. (2018) Mobility capital: Somali migrants negotiating social inequalities across borders. Geoforum. https://doi.org/10.1016/j.geoforum.2017.12.002 
Mountz, A. (2004) Embodying the nation-state: Canada's response to human smuggling. Political Geography 23 (3): 323-345.

Mountz, A. and J. Hyndman (2006) Feminist Approaches to the Global Intimate. Women's Studies Quarterly 34 (1 and 2): 446-463.

Nagar, R., V. Lawson, L. McDowell and S. Hanson (2002) Locating Globalization: Feminist (Re)readings of the Subjects and Spaces of Globalization. Economic Geography 78 (3): 257-284.

Nash, J.C. (2008) re-thinking intersectionality. feminist review 89: 1-15.

OIM (2013) Perfil migratorio de Nicaragua 2012. Managua: Organización Internacional para las Migraciones.

Pink, S. (2011) 'From embodiment to emplacement: re-thinking competing bodies, senses and spatialities', Sport, Education and Society 16 (3): 343-355.

Robinson, W.I. (2003) Transnational Conflicts. Central America, Social Change, and Globalization. London: Verso.

Ryburn, M. (2016) Living the Chilean dream? Bolivian migrants' incorporation in the space of economic citizenship. Geoforum 76: 48-58.

Sandoval-García, C. (2013) To whom and to what is research on migration a contribution. Ethnic and Racial Studies 36 (9): 1429-1445.

Silvey, R. (2005) Borders, Embodiment, and Mobility: Feminist Migration Studies in Geography. In L. Nelson and J. Seager (eds.) A Companion to Feminist Geography. Blackwell, pp. 138-149. 
Schapendonk, J. and G. Steel (2014) Following Migrant Trajectories: The Im/Mobility of Sub-Saharan Africans en Route to the European Union. Annals of the Association of American Geographers 104 (2): 262-270.

Schmoll, C. (2014) Gendered spatialities of power in 'borderland' Europe: an approach through mobile and immobilised bodies. International Journal of Migration and Border Studies 1 (2): 173-189.

Sheller, M. and J. Urry (2006) The new mobilities paradigm. Environment and Planning A 38: 207-226.

Sinatti, G. (2014) Masculinities and Intersectionality in Migration: Transnational Wolof Migrants Negotiating Manhood and Gendered Family Roles. In T.D. Truong et al. (eds.) Migration, Gender and Social Justice: Perspectives on Human Insecurity. Hexagon Series on Human and Environmental Security and Peace 9, pp. 215-226.

Steel, G., N. Winters and C. Sosa (2011) Mobility, translocal development and the shaping of development corridors in (semi-)rural Nicaragua. International Development Planning Review 33 (4): 409-428.

Tamagno, C. (2002) You must win their affection... Migrants' social and cultural practices between Peru and Italy. In K. Fog Olwig and N. Nyberg Sørensen (eds.) Work and Migration: Life and Livelihoods in a Globalizing World. London: Routledge, pp. 106-125.

Vaiou, D. (2012) Gendered mobilities and border-crossings: from Elbasan to Athens. Gender, Place and Culture 19 (2): 249-262.

Vaittinen, T. (2014) Reading global care chains as migrant trajectories. A theoretical framework for the understanding of structural change. Women's Studies International Forum 47 Part B: 191-202. 
Werner, M. (2010) Embodied negotiations: identity, space and livelihood after trade zones in the Dominican Republic. Gender, Place and Culture 17 (6): 725-741.

Winters, N., 2014. Responsibility, mobility, and power: Translocal carework negotiations of Nicaraguan families. International Migration Review 48 (2), 415-441.

Winters, N., 2016. Contested connections. Mobility and migration as development experiences of translocal livelihoods in Muy Muy, Nicaragua. unpublished PhD thesis. University of Antwerp, Institute of Development Policy and Managment, Antwerp.

\section{Highlights}

- Border-crossing involves migrants' context-specific bodily performances.

- Domestic employment requires and sustains gendered and racialized bodies.

- Cross-border bodily circulation is based on the appropriateness of specific bodies.

- Migrant bodies can be used as resources for improving living and working conditions.

- Migrant marginalization abroad and (expected) privilege at home exist side by side. 